\title{
Bioactive compounds and antioxidant activity in fruits of clone and ungrafted genotypes of yellow mombin tree
}

\author{
Compostos bioativos e capacidade antioxidante de frutos de genótipos clones e pés-franco de cajazeira
}

\author{
Fernanda Vanessa Gomes da SILVA ${ }^{1 \star}$, Silvanda de Melo SILVA², Gerciane Cabral da SILVA 3 , \\ Rejane Maria Nunes MENDONÇA ${ }^{4}$, Ricardo Elesbão ALVES ${ }^{5}$, Ana Lima DANTAS ${ }^{6}$
}

\begin{abstract}
Yellow mombin is a fruit tree that grows spontaneously in the Semi-Arid Northeastern Brazil. Its fruits are still extractively exploited. The pulp of yellow mombin fruit stands out regarding the commercial aspect due to the characteristic flavor and aroma felt when consumed in diverse ways. This study aimed to evaluate the presence of bioactive compounds, total extractable polyphenols, and antioxidant activity of yellow mombin fruits (Spondias mombin, L.), from clone and ungrafted genotypes. The fruits were harvested at commercial maturity from twelve yellow mombin tree genotypes from an experimental orchard located at the municipality of Joao Pessoa, Paraíba, Brazil, and evaluated for chlorophyll, carotenoids, yellow flavonoids, total extractable polyphenols, and antioxidant activity, which was measured by the $\beta$-carotene/ linoleic acid method. The antioxidant activity showed a percentage of inhibition of oxidation higher than $75 \%$ for all genotypes evaluated at the time of 120 minutes. The fruits from clone genotypes showed a higher percentage of antioxidant activity.

Keywords: Spondias mombin L.; carotenoids; polyphenols; yellow flavonoids; inhibition of oxidation; plant breeding.
\end{abstract}

\section{Resumo}

A cajazeira é uma árvore frutífera de ocorrência espontânea no Semiárido Nordestino e seus frutos são ainda explorados de forma extrativista. A polpa do fruto da cajazeira assume posição de destaque no que tange ao aspecto comercial, em função do aroma e do sabor característicos que oferece quando degustada nas mais variadas formas. Este trabalho teve como objetivo avaliar a presença de compostos bioativos e polifenóis extraíveis, e a atividade antioxidante de frutos da cajazeira (Spondias mombin, L), provenientes de genótipos clones e pés-franco. Os frutos foram colhidos na maturidade comercial de doze genótipos de cajazeiras provenientes de pomar experimental localizado no Município de João Pessoa-PB, Brazil, e avaliados quanto ao teor de clorofila, carotenoides, flavonoides amarelos e polifenóis extraíveis totais, sendo a atividade antioxidante avaliada pelo método $\beta$-caroteno/ácido linoleico. A atividade antioxidante apresentou um percentual de inibição da oxidação superior a 75\% para todos os genótipos em estudo no tempo de 120 minutos. Frutos provenientes de genótipos clones apresentaram um maior percentual de atividade antioxidante do que aqueles de pés-franco.

Palavras-chave: Spondias mombin L.; carotenoides; polifenóis; flavonoides amarelos; inibição da oxidação; melhoramento genético.

\section{Introduction}

A major concern for fruit growers in the Northeast of Brazil is adding value to underexploited fruits, which have been getting much attention due to their increased market potential focusing on supply diversification (SOUZA et al., 2010).

There is a wide range of fruits - native and exotic - which are conventionally called "potencials". Currently, they occupy roughly the same space once reserved for species already recognized and commercially produced all over Brazil (EMPRESA..., 2011). Among the native fruits with antioxidant potential, those of the genus Spondias can be highlighted (LORENZI, 2006). However, the ungrafted naturally occurring yellow mombin tree is a woody tropical fruit with long and erect forked-shaped stem, which is coated with a thick and rough shell. It is a very tall plant of difficult handling (SOUZA et al., 2006). Based on that, plant breeding aims to develop more productive lines of fruit trees (CASSIMIRO; MACÊDO; MENINO, 2009), of easier handling (SOUZA et al., 2006), and high quality fruits (DANTAS JÚNIOR, 2008).

Yellow mombin fruit has increased participation in the agribusiness of the North and Northeast regions of Brazil (AZEVEDO; MENDES; FIGUEIREDO, 2004; TODA FRUTA, 2006; CAVALCANTE et al., 2009; FRAIFE FILHO; LEITE; RAMOS, 2010), mainly as fresh fruit and processed pulp. It has great market acceptance for its distinctive flavor and exotic aroma, and, therefore, high commercial value as raw material in the preparation of juice, ice creams, liquors, nectars, and jellies

\footnotetext{
Received 12/6/2010

Accepted 20/5/2012 (004885)

${ }^{1}$ Universidade Federal da Paraíba - UFPB, CEP 58051-970, João Pessoa, PB, Brasil, e-mail: fvgs2004@yahoo.com.br

${ }^{2}$ Universidade Federal da Paraíba - UFPB, Campus de Areia, CP 04, CEP 58397-970, Areia, PB, Brasil

${ }^{3}$ Estação experimental Cientista José Irineu Cabral - EECJIC, Empresa de Pesquisa Agropecuária da Paraíba - EMEPA-PB, João Pessoa, PB, Brasil

${ }^{4}$ Departamento de Fitotecnia e Ciências Ambientais, Universidade Federal da Paraíba - UFPB, CEP 58397-000, Areia, PB, Brasil

${ }^{5}$ Empresa de Pesquisa Agropecuária da Paraíba - Embrapa Agroindústria Tropical, Rua Dra. Sara Mesquita, 2270, Pici, CEP 60110-520, Fortaleza, PE, Brasil

${ }^{6}$ Universidade Federal da Paraíba - UFPB, CEP 58397-000, Areia, PB, Brasil

${ }^{*}$ Corresponding author
} 
(SOUZA et al., 2006; 2010). In Northeastern Brazil, the demand for yellow mombin pulp is greater than other commercialized fruit pulps (FRAIFE FILHO; LEITE; RAMOS, 2010); however, its industrialization is totally dependent on seasonal variation in fruit taking into account the extractive exploitation of the yellow mombin tree and the elevated fruit losses due to poor harvesting practices, postharvest handling, and transportation (MOURA et al., 2004; 2009; SOARES et al., 2006). Thus, although the yellow mombin pulp has aroused interest in other regions of the country, the current industrial production is still not enough to meet the demands of the consumer market of the Northern and Northeastern regions (TODA FRUTA, 2006; FRAIFE FILHO; LEITE; RAMOS, 2010).

Therefore, the increased demand for yellow mombin fruits has attracted interest to the cultivation of this species, which is still considered in the process of domestication with little information about the establishment of commercial orchards (SOUZA et al., 2006). Its inclusion as a fruit species in the modern agronomic models requires, however, the identification of propagated materials whose genotypes that in addition to having high productive capacity (AZEVEDO; MENDES; FIGUEIREDO, 2004; CASSIMIRO; MACÊDO; MENINO, 2009; SOUZA et al., 2010) can produce fruits with superior functional quality (SOARES et al., 2006; DANTAS JÚNIOR, 2008).

The emphasis in searching for foods that contribute to healthy eating has increased strongly around the world. A varied, balanced diet rich in colorful food is the assurance of consumption of all essential and recommended nutrients (LAJOLO, 2006 apud ALVES; BRITO; RUFINO, 2006). In addition to essential macro and micronutrients, daily diet provides some chemical compounds that are mostly present in fruits and vegetables with potent biological activity due to their free radical scavenging ability (RICE-EVANS; MILLER; PAPAGANDA, 1996). They are called bioactive compounds or, sometimes, phytochemicals, and they can play several roles with benefits for human health (CARRATU; SANZINI, 2005).

The study of bioactive compounds in food gave rise to the concept of functional foods, originated in Japan in the 1980's when it was used by industries to describe foods fortified with specific ingredients inferring health benefits (AMARAMOKRANE et al., 1996). Bioactive compounds are extra nutritional constituents and typically occur in small amounts in foods (PIETTA, 2000). Epidemiological studies, dealing with diets rich in fruits and vegetables, suggest that these foods are able to exert influence in reducing the risk of developing chronic non-transmissible diseases such as cardiovascular, cancer, metabolic disorders, neurodegenerative, and inflammatory diseases (CARRATU; SANZINI, 2005). Yellow mombin fruit is rich in carotenoids (RODRIGUEZ-AMAYA; KIMURA, 1989, MOURA et al., 2004); therefore, it is necessary to evaluate the contribution of carotenoids to the antioxidant potential as a way to add value to this fruit as functional food since, according to Lajolo (2006), any claim that a food product has health benefits has to be based on scientific evidences.

Bioactive compounds are mostly secondary metabolites of plants (RICE-EVANS; MILLER; PAPAGANDA, 1996); their polyphenols are the most abundant (ROSA; ALVAREZPARRILLA; GONZÁLEZ-AGUILAR, 2010) and are usually related to defense against ultraviolet radiation or aggression by pathogens or insects (ZULUETA et al., 2007). Since they exist in large numbers, several classes of polyphenols can be grouped according to the number of phenol rings and to the structural elements that bind these rings (CARRATU; SANZINI, 2005). Therefore, two main groups of polyphenols, termed flavonoids (flavonones, flavones, dihydroflavonols, flavonols, flavan-3ols, anthocyanidins, isoflavones, and proanthocyanidins) and non-flavonoids (simple phenols, benzoic acids, hydrolysable tannins, acetophenones and phenylacetic acids, cinnamic acids, coumarins, benzophenones, xanthones, stilbenes, chalcones, lignans, and secoiridoids), have been traditionally adopted (ROSA; ALVAREZ-PARRILLA; GONZÁLEZ-AGUILAR, 2010). Some of those are specific to some species or genus of plants (CARRATU; SANZINI, 2005).

Since most bioactive phytochemicals have antioxidant capacity, the sum of the contribution of all oxidants is the total antioxidant capacity (RICE-EVANS; MILLER; PAPAGANDA, 1996). Moreover, the antioxidant compounds found in fruits and vegetables can cause inhibition or synergy between them (ZULUETA et al., 2007). Thus, in addition to evaluating each bioactive compound isolatedly, it is important to study the antioxidant potential in a broader context, i.e., considering the total extract of the fruit (ROMBALDI et al., 2006).

Therefore, the objective of this study was to evaluate the presence of bioactive compounds, total extractable polyphenols, and antioxidant activity of yellow mombin fruits from clone and ungrafted genotypes.

\section{Material and methods}

\subsection{Material}

Twelve yellow mombin tree genotypes from the germplasm collection of EMEPA-PB, João Pessoa - PB were selected. From these selected trees, six were clones (G1, G2, G3, G4, G5 e G6 plants) and six were ungrafted (G7, G8, G9, G10, G11 e G12 plants).

Yellow mombin fruits were manually harvested from each genotype, early in the morning, at the commercial maturity (yellow color with green stains) from EMEPA's experimental orchard. After harvest, the fruits were transported in isothermal boxes to the Laboratório de Biologia e Tecnologia Pós-Colheita of the Centro de Ciências Agrárias of the Universidade Federal da Paraíba and selected according to appearance and absence of physical or physiological damages. Fruit pulp was manually extracted and frozen at $-86^{\circ} \mathrm{C}$ for evaluation.

\subsection{Methods}

\section{Bioactive compounds}

To determine Total Chlorophyll (mg. $\left.100 \mathrm{~g}^{-1}\right)$ around $1 \mathrm{~g}$ of fresh pulp was used; it was ground in a mortar with washed and dried sand in the presence of $5 \mathrm{~mL}$ of $80 \%$ acetone solution and $5 \mathrm{mg} \mathrm{CaCO}$. The extract was left 24 hours in the dark at $4{ }^{\circ} \mathrm{C}$, 
according to Arnon (1985), and the total chlorophyll content was calculated as described by Silva (2008).

Total Carotenoids ( $\mu$ g. $\mathrm{g}^{-1}$ pulp) it was quantified according to Dantas Júnior (2008), using $5 \mathrm{~g}$ of frozen pulp, $15 \mathrm{~mL}$ of of isopropyl alcohol, and $5.0 \mathrm{~mL}$ of hexane, followed by stirring for 1 minute. The content was transferred to a $125 \mathrm{~mL}$ amber separatory funnel, and the total volume was completed with distilled water. The material was left to rest for 30 minutes, followed by washing; this procedure was repeated twice. Next, it was filtered through cotton tissue sprayed with anhydrous sodium sulfate, transferred to a $25 \mathrm{~mL}$ volumetric flask, and wrapped with aluminum foil, to which it was added $2.5 \mathrm{~mL}$ of acetone and diluted with hexane. Absorbance was measured at $450 \mathrm{~nm}$.

Yellow Flavonoids (mg.100 $\mathrm{g}^{-1}$ ) were measured in a spectrophotometer according to the method of Lees and Francis (1972) using $1 \mathrm{~g}$ of frozen pulp, followed by the extraction of flavonoids with $30 \mathrm{~mL}$ of the extracting solution (95\% ethanol and $1.5 \mathrm{~N} \mathrm{HCl}$ at the rate of 85:15 v/v). The extract was left overnight in the refrigerator and filtered; absorbance was measured at $374 \mathrm{~nm}$, and the contents calculated as described by Dantas Júnior (2008).

\section{Extraction of polyphenols and antioxidants}

A total of $20 \mathrm{~g}$ of frozen pulp was weighed and cold extraction $\left(\approx 10{ }^{\circ} \mathrm{C}\right)$ was performed using $40 \mathrm{~mL}$ of methanol/ water $(50: 50 \mathrm{v} / \mathrm{v})$ solution, which was left to extract for 1 hour.

Next, the samples were centrifuged at 15,000 rpm for 15 minutes at $5{ }^{\circ} \mathrm{C}$. The supernatant was filtered and transferred to a $100 \mathrm{~mL}$ volumetric flask; the residue was transferred to a Beaker by adding $40 \mathrm{~mL}$ of acetone/water solution $(70: 30 \mathrm{v} / \mathrm{v})$ and left to extract for 1 hour. Centrifugation was repeated and the supernatant was filtered and added to the volumetric flask that already contained the supernatant of the first extraction, and the total volume was completed with distilled water (LARRAURI; PUPÉREZ; SAURA-CALIXTO, 1997). The extracts were used for determination of antioxidant capacity and total extractable polyphenols.

\section{Quantification of the total extractable polyphenols (TEP)}

The total extractable polyphenols were determined by the method of Folin-Ciocalteu using the supernatant of the extraction. In test tubes, it was placed an aliquot of $0.1 \mathrm{~mL}$ of the extract added of $0.9 \mathrm{~mL}$ of distilled water. The extracts were mixed with $1 \mathrm{~mL}$ of Folin-Ciocalteu reagent, $2 \mathrm{~mL}$ of $20 \%$ sodium carbonate solution and $2 \mathrm{~mL}$ of distilled water. The tubes were stirred and, after 30 minutes the absorbance was measured in a spectrophotometer at $700 \mathrm{~nm}$ and the result expressed in $\mathrm{mg} .100 \mathrm{~g}^{-1}$ of gallic acid (OBANDA; OWUOR, 1997).

Evaluation of the antioxidant activity by the system $\beta$-Carotene/Linoleic acid method

The antioxidant activity was determined by the method described by Miller (1971) and later modified by Rufino et al. (2006) based on the oxidation (discoloration) of $\beta$-carotene and induced by the products of the oxidative degradation of linoleic acid. Solutions were prepared using $5 \mathrm{~mL}$ of the $\beta$-carotene/ linoleic acid system and $0.4 \mathrm{~mL}$ of the fruit extract/Trolox in different concentrations. The absorbance readings were taken immediately and at intervals of 15 minutes for 120 minutes using a spectrophotometer at $470 \mathrm{~nm}$, keeping the tubes in a water bath at $50{ }^{\circ} \mathrm{C}$. The results were expressed in percentage of inhibition of oxidation, in comparison to that of the antioxidant standard used (Trolox) according to Dantas Júnior (2008).

\section{Statistical analysis}

Three replications were performed for all parameters evaluated ( $2 \mathrm{~kg}$ of fruit/genotype). The results were expressed as mean and standard deviation using SPSS for Windows Evaluation Edition - 14.0 (STATISTICAL..., 2005). The data were submitted to analysis of variance (ANOVA - F test), and the means compared by the Duncan test at $5 \%$ probability of error. For correlations, the Pearson correlation coefficient $(r)$ was applied.

\section{Results and discussion}

\subsection{Quantification of bioactive compounds}

The content of bioactive compounds of fruits of twelve yellow mombin tree genotypes are presented in Table 1.

The mean content of total chlorophyll for yellow monbin fruit pulp harvested from different genotypes ranged from 0.20 to $0.61 \mathrm{mg} .100 \mathrm{~g}^{-1}$ of pulp. The highest content was found for the clone genotype G1, and the lowest was found for the fruits harvested from the ungrafted genotype G7.

The low total chlorophyll content found in the fruit pulp is due to the commercial maturity stage at harvest; in which the fruits are mostly yellow with some green spots.

Table 1. Bioactive compounds in fruits harvested at commercial maturity from 12 clone and ungrafted genotypes of yellow mombin trees.

\begin{tabular}{llccc}
\hline \multicolumn{2}{c}{ Genotype } & $\begin{array}{c}\text { Total chlorophyll } \\
\left(\mathrm{mg} .100 \mathrm{~g}^{-1}\right)\end{array}$ & $\begin{array}{c}\text { Carotenoids } \\
\left(\mu \mathrm{g}^{-1}\right)\end{array}$ & $\begin{array}{c}\text { Yellow flavonoids } \\
\left(\mathrm{mg} .100 \mathrm{~g}^{-1}\right)\end{array}$ \\
\hline Clone & G1 & $0.61 \pm 0.03^{\mathrm{a}}$ & $40.68 \pm 2.4^{\mathrm{b}}$ & $2.02 \pm 0.10^{\mathrm{de}}$ \\
& G2 & $0.32 \pm 0.02^{\text {cde }}$ & $21.81 \pm 0.5^{\mathrm{e}}$ & $1.82 \pm 0.20^{\mathrm{e}}$ \\
& G3 & $0.29 \pm 0.03^{\text {def }}$ & $51.47 \pm 3.2^{\mathrm{a}}$ & $1.37 \pm 0.12^{\mathrm{f}}$ \\
& G4 & $0.27 \pm 0.02^{\text {def }}$ & $37.41 \pm 1.4^{\mathrm{c}}$ & $1.82 \pm 0.13^{\mathrm{e}}$ \\
& G5 & $0.58 \pm 0.02^{\mathrm{a}}$ & $38.69 \pm 0.2^{\mathrm{bc}}$ & $4.39 \pm 0.07^{\mathrm{b}}$ \\
& G6 & $0.25 \pm 0.01^{\mathrm{fg}}$ & $38.69 \pm 0.2^{\mathrm{bc}}$ & $5.25 \pm 0.22^{\mathrm{a}}$ \\
& G7 & $0.20 \pm 0.04^{\mathrm{g}}$ & $10.17 \pm 0.3^{\mathrm{h}}$ & $2.00 \pm 0.17^{\mathrm{de}}$ \\
& G8 & $0.37 \pm 0.03^{\mathrm{c}}$ & $12.22 \pm 1.6^{\mathrm{gh}}$ & $1.98 \pm 0.08^{\mathrm{de}}$ \\
& G9 & $0.27 \pm 0.02^{\mathrm{ef}}$ & $14.76 \pm 0.7^{\mathrm{fg}}$ & $2.18 \pm 0.22^{\mathrm{d}}$ \\
& G10 & $0.34 \pm 0.02^{\mathrm{cd}}$ & $25.21 \pm 1.7^{\mathrm{d}}$ & $2.98 \pm 0.27^{\mathrm{c}}$ \\
& G11 & $0.48 \pm 0.03^{\mathrm{b}}$ & $16.49 \pm 1.4^{\mathrm{f}}$ & $2.72 \pm 0.10^{\mathrm{c}}$ \\
& G12 & $0.31 \pm 0.07^{\mathrm{def}}$ & $12.48 \pm 0.8^{\mathrm{gh}}$ & $2.90 \pm 0.19^{\mathrm{c}}$ \\
\hline
\end{tabular}

a,b,c Means ( \pm Standard Error) followed by the same letters in the column do not differ among genotypes by the Duncan test at $5 \%$ of probability. 
Chlorophyll degradation occurs during the maturation of fruits as a function of the activity of the chlorophyllase, peroxidase enzymes, and also by direct action of light (IKEMEFUNA; ADAMSON, 1984).

Studies have attributed to chlorophyll and its synthetic derivative, copper chlorophyllin, a potent antimutagenic activity (CHERNORMORSKY et al., 1999; DASHWOOD et al., 1998; ODIN, 1997). These substances can act on mechanisms related to DNA repair removing substances that may cause changes, or, by the action of an antioxidant, they can prevent DNA damage. Based on these mechanisms, in vitro tests have also shown that chlorophyll, pheophytin, and copper chlorophyllin are strong inhibitors of the formation of adduct of carcinogen substances (aflatoxin B1 and dibenzo [a, 1] pyrene) with DNA (BREINHOLT et al., 1995; HARTTIG; BAILEY, 1998).

With regard to carotenoid contents in the yellow mombin fruits evaluated, clone genotype G3 showed the highest content $\left(51.47 \mu \mathrm{g} . \mathrm{g}^{-1}\right)$, and the lowest was detected in the ungrafted genotype G7 (10.17 $\left.\mu \mathrm{g} \cdot \mathrm{g}^{-1}\right)$, according to Table 1. The levels of carotenoids in yellow mombin fruit are, therefore, higher than those found in 'Tommy Atkins' mango $\left(\approx 3.3 \mathrm{mg} .100 \mathrm{~g} \mathrm{~g}^{-1}\right.$ equivalent to $33 \mu \mathrm{g} \cdot \mathrm{g}^{-1}$ ) at maturity stage (LIMA; SILVA; AZEVEDO, 2009). The fact that carotenoids have antioxidant activity and are the vitamin A precursors (PALOZZA; KRINSKY, 1992) makes these results very important for human life since this widely consumed fruit in Brazilian Semi-Arid could be better used for the prevention of various diseases, among which are eyesight problems caused by vitamin A deficiency and diseases that result from oxidative stress, such as cancer (PALACE et al., 1999).

These results for total carotenoids are in accordance with those reported by Moura et al. (2009) that found values ranging from 19.81 to $43.33 \mu \mathrm{g} . \mathrm{g}^{-1}$ for different yellow mombin genotypes from the germplasm bank of IPA-PE, Brazil. For yellow mombin processed products, Rodriguez-Amaya and Kimura (1989) found values of $20.6 \mu \mathrm{g} \cdot \mathrm{g}^{-1}$ for total carotenoids in frozen pulp and Hamano and Mercadante (2001); when evaluating commercial products, they found values of $20.6 \mu \mathrm{g} . \mathrm{g}^{-1}$ for pulp and $16.7 \mu \mathrm{g} . \mathrm{g}^{-1}$ for juice.

Carotenoid content of fruit increases during maturation and ripening (MOURA et al., 2004); however, part of color intensification is due to the chlorophyll degradation (IKEMEFUNA; ADAMSON, 1984). The carotenoid contents in vegetables, on the other hand, can be affected by maturity stage, type of soil, growing and climatic conditions, cultivar, part of plant consumed, use of pesticides, exposure to sunlight, processing conditions, and storage (RODRIGUEZ-AMAYA, 2000).

Carotenoids action against diseases has been attributed to the antioxidant activity, specifically to their ability to quench singlet oxygen and its interactions with free radicals (PALOZZA; KRINSKY, 1992; PALACE et al., 1999). However, other mechanisms have been reported such as modulation of carcinogen metabolism, regulation of cell growth, inhibition of cell proliferation, enhancement of cell differentiation, stimulation of cell-to-cell communication, retinoid-dependent signaling, and filtering of blue light (KRINSKY; JOHNSON, 2005; STAHL; SIES, 2005).

As for the yellow flavonoids (Table 1), it was observed a small variation between the different genotypes, with the minimal content of $1.37 \mathrm{mg} .100 \mathrm{~g}^{-1}$ for clone genotype G3 and a maximum of $5.25 \mathrm{mg} .100 \mathrm{~g} \mathrm{~g}^{-1}$ for ungrafted genotype G6. As for the yellow mombin pulp, Rufino (2008) reported values for yellow flavonoids in the order of $7.1 \mathrm{mg} \cdot 100 \mathrm{~g}^{-1}$.

Most of the beneficial health effects of flavonoids are attributed to their antioxidant and chelating abilities. By virtue of their capacity to inhibit LDL oxidation, flavonoids have demonstrated unique cardioprotective effects (KONDO et al., 1996; MAZUR et al., 1999).

\subsection{Total extractable polyphenols and antioxidant activity by $\beta$-Carotene/Linoleic acid system}

The values for total extractable polyphenols (TEP) and the percentage of oxidation inhibition are presented in Table 2 .

In yellow mombin fruits, the content of TEP varied from $29.12 \mathrm{mg} .100 \mathrm{~g}^{-1}$, for ungrafted genotype G9, to $102.88 \mathrm{mg} .100 \mathrm{~g} \mathrm{~g}^{-1}$, for clone genotype G4 (Table 2). These values are higher than those found for buriti pulp (9.46 mg.100 $\mathrm{g}^{-1}$ ) (MANHÃES; SABAA-SRUR, 2011). Polyphenols have antioxidant activity and, based on their antioxidant function, these compounds possess anti-atherosclerotic, anti-inflammatory, antitumor, antithrombotic, anti-osteoporosis, and antiviral activities (ROSA; ALVAREZ-PARRILLA; GONZÁLEZ-AGUILAR, 2010). Therefore, the data presented herein is of great relevance to human health in Brazilian Semi-Arid region given the recognized potential of polyphenols to prevent diseases caused by oxidative stress (RICE-EVANS; MILLER; PAPAGANDA, 1996; ZULUETA et al., 2007).

In fruits of umbu tree (Spondias tuberosa Arr. Cam.) harvested from 32 genotypes, Dantas Júnior (2008) found

Table 2. Total extractable polyphenols (TEP) and inhibition of oxidation in fruits harvested at commercial maturity from 12 clone and ungrafted genotypes of yellow mombin trees.

\begin{tabular}{lccc}
\hline \multicolumn{2}{c}{ Genotype } & $\begin{array}{c}\text { TEP } \\
\left(\mathrm{mg} .100 \mathrm{~g}^{-1}\right)\end{array}$ & $\begin{array}{c}\text { Inhibition of } \\
\text { Oxidation }(\%)\end{array}$ \\
\hline Clone & G1 & $42.75 \pm 2.0^{\mathrm{f}}$ & $86.47 \pm 0.4^{\mathrm{g}}$ \\
& G2 & $65.50 \pm 3.0^{\mathrm{bc}}$ & $92.83 \pm 0.3^{\mathrm{c}}$ \\
& G3 & $34.86 \pm 1.0^{\mathrm{g}}$ & $90.10 \pm 0.9^{\mathrm{d}}$ \\
& G4 & $102.88 \pm 3.0^{\mathrm{a}}$ & $97.42 \pm 0.0^{\mathrm{a}}$ \\
& G5 & $53.69 \pm 2.8^{\mathrm{e}}$ & $94.27 \pm 0.6^{\mathrm{b}}$ \\
& G6 & $58.32 \pm 0.3^{\mathrm{de}}$ & $95.07 \pm 0.3^{\mathrm{b}}$ \\
& G7 & $70.96 \pm 5.2^{\mathrm{b}}$ & $89.58 \pm 0.1^{\mathrm{de}}$ \\
& G8 & $71.41 \pm 3.5^{\mathrm{b}}$ & $89.01 \pm 0.6^{\mathrm{ef}}$ \\
& G9 & $29.12 \pm 1.3^{\mathrm{g}}$ & $76.65 \pm 0.3^{\mathrm{j}}$ \\
& G10 & $29.34 \pm 4.0^{\mathrm{g}}$ & $88.58 \pm 0.4^{\mathrm{f}}$ \\
& G11 & $29.05 \pm 9.0^{\mathrm{g}}$ & $83.74 \pm 0.6^{\mathrm{i}}$ \\
& G12 & $62.49 \pm 7.0^{\mathrm{cd}}$ & $84.82 \pm 0.6^{\mathrm{h}}$ \\
\hline
\end{tabular}

a,b,c Means ( \pm Standard Error) followed by the same letters in the column do not differ among genotypes by the Duncan test at $5 \%$ of probability. 
total extractable polyphenols values varying from 21.26 to $49.66 \mathrm{mg} .100 \mathrm{~g}^{-1}$, which are much lower than the TEP values found in the present study for yellow mombin fruits.

The $\beta$-carotene/linoleic acid system is based on $\beta$-carotene discoloration induced by the products of linoleic acid oxidation. Therefore, the utilization of antioxidants retards the decline of $\beta$-carotene absorbance protecting lipid substrates from oxidation (KONDO et al., 1996).

The results of the oxidation inhibition (\%) by the $\beta$-carotene/ Linoleic Acid System of yellow mombin fruit extracts are shown in Table 2. Ungrafted genotypes had the lowest percentages of oxidation inhibition with values ranging from 76.65 to $89.58 \%$. In turn, the clones had values ranging from 86.47 to $97.42 \%$, similarly to the results reported by Rufino (2008) in studies with pulp of yellow mombin fruit $(92.7 \%)$. On the other hand, Silva (2008), in studies with fruits from different genotypes of the Spondias hybrid umbu-yellow mombin tree, reported values of $60.93 \%$ of oxidation inhibition.

Table 3 presents the correlations among the bioactive attributes, total extractable polyphenols, and inhibition of oxidation.

The Pearson correlation may provide powerful information about the dynamics between attributes improving the validity of results. Thus, the forces of $(-) 1$ to +1 , shown in Table 3 , can be interpreted as positive $(+)$ and reverse $(-)$, none $(0.0)$, negligible ( 0.01 to 0.09 ), low ( 0.10 to 0.29 ), moderate ( 0.30 to 0.49 ), substantial ( 0.5 to 0.69$)$, and severe $(\geq 0.70)$. Accordingly, for the bioactive compounds, in general, the yellow flavonoids showed a very strong positive correlation $(p \leq 1 \%)$ with the percentage of inhibition of oxidation and a substantial correlation with the total extractable polyphenols content. The contents of chlorophyll and carotenoids showed a substantial positive correlation with the percentage of inhibition of oxidation ( $\mathrm{p} \leq 1 \%$ ); in turn, the correlation among chlorophyll and carotenoids and the total extractable polyphenols was ( $\mathrm{p} \leq 1 \%)$ moderately positive.

Table 3. Correlation among the bioactive compounds, total extractable polyphenols (TEP), and inhibition of oxidation in fruits from 12 clone and ungrafted genotypes of yellow mombin trees.

\begin{tabular}{|c|c|c|c|c|c|}
\hline \multirow{2}{*}{ Attribute } & \multicolumn{5}{|c|}{$\begin{array}{l}\text { Test of Correlation of Pearson and Probability among } \\
\text { Attributes in Yellow mombin fruits }\end{array}$} \\
\hline & $\begin{array}{c}\text { Inhibitio of } \\
\text { oxidation }\end{array}$ & TEP & Carotenoids & $\begin{array}{c}\text { Total } \\
\text { chlorophyll }\end{array}$ & $\begin{array}{c}\text { Yellow } \\
\text { flavonoids }\end{array}$ \\
\hline $\begin{array}{l}\text { Inhibition } \\
\text { of oxidation }\end{array}$ & 1.00 & $0.38^{*}$ & $0.63^{* *}$ & $0.60^{\star \star}$ & $0.76^{* *}$ \\
\hline TEP & - & 1.00 & -0.17 & $0.73^{\star *}$ & $0.49^{\star \star}$ \\
\hline Carotenoids & - & - & 1.00 & 0.23 & $0.64^{* *}$ \\
\hline $\begin{array}{l}\text { Total } \\
\text { chlorophyll }\end{array}$ & - & - & - & 1.00 & $0.87^{\star *}$ \\
\hline $\begin{array}{l}\text { Yellow } \\
\text { flavonoids }\end{array}$ & - & - & - & - & 1.00 \\
\hline
\end{tabular}

$\left.{ }^{*}\right)$ Indicates probability of error $\leq 5 \%$; $\left({ }^{*}\right)$ Indicates probability of error $\leq 1 \%$; ${ }^{\text {CCorrelation }}$ of Pearson (forces from -1 to +1 ).

\section{Conclusions}

It can be concluded that the pulp of yellow mombin fruits evaluated present high percentage of inhibition of oxidation, which is strongly correlated with yellow flavonoids, carotenoids, and chlorophyll with substantial contents of these biologically active compounds, in addition to extractable phenolic compounds, and it seems to be a potential source of natural antioxidants for the human diet.

In general, fruits from clone genotype showed higher antioxidant activities.

However, further studies are necessary to characterize the structure of these functional substances and to confirm their beneficial effects on human health.

\section{Acknowledgements}

The authors gratefully acknowledge $\mathrm{CNPq}$ for the financial support and CAPES for the fellowship granted to the first author.

\section{References}

ALVES, R. E.; BRITO, E. S.; RUFINO, M. S. M. Prospecção da atividade antioxidante e de compostos com propriedades funcionais em frutas tropicais. In: CONGRESSO BRASILEIRO DE FRUTICULTURA - CBF, 19., 2006, Cabo Frio. Palestras e resumos... Cabo frio: SBF/UENF/UFRuralRJ, 2006. p. 133-141.

AMARA-MOKRANE, Y. A. et al. Protective effects of a-hederin, chlorophyllin and ascorbic acid towards the induction of micronuclei by doxorubicin in cultured human lymphocytes. Mutagenesis, v. 11, n. 2, p. 161-167, 1996. http://dx.doi.org/10.1093/ mutage/11.2.161

ARNON, D. I. Cooper enzymes infisolated chloroplasts. Polyphenoloxidases in Beta vulgaris. Plant Physiology, v. 24, n. 1, p. 1-15, 1985. http://dx.doi.org/10.1104/pp.24.1.1

AZEVEDO, D. M.; MENDES, A. M. S.; FIGUEIREDO, A. F. Característica da germinação e morfologia do endocarpo e plântula de taperebá (Spondias mombin L.) - Anarcadiaceae. Revista Brasileira de Fruticultura, v. 26, n. 3, p. 534-537, 2004.

BREINHOLT, V. et al. Dietary chlorophyllin is a potent inhibitor of aflatoxin B1 hepatocarcinogenesis in rainbow trout. Cancer Research, v. 55, n. 1, p. 57- 62, 1995.

CARRATU, E.; SANZINI, E. Sostanze biologicamente attive presenti negli alimenti di origine vegetable. Annali dell'Istituto Superiore di Sanita, v. 41, n. 1, p. 7-16, 2005.

CASSIMIRO, C. M.; MACÊDO, L. S.; MENINO, I. B. Avaliação de acessos de cajazeira (Spondias mombin) do Banco Ativo de Germoplasma da Emepa, PB. Tecnologia \& Ciência Agropecuária, v. 3, p. 1-6, 2009.

CAVALCANTE, L. F. Componentes qualitativos do cajá em sete municípios do brejo paraibano. Acta Scientiarum Agronomy, v. 31 , n. 4 , p. $627-632,2009$.

CHERNORMORSKY, S.; SEGELMAN, A.; PORETZ, R. D. Effect of dietary chlorophyll derivatives on mutagenesis and tumor cell growth. Teratogenesis, carcinogenesis, and mutagenesis, v. 19 , p. $313-322,1999$. http://dx.doi.org/10.1002/(SICI)15206866(1999)19:5<313::AID-TCM1>3.0.CO;2-G

DANTAS JÚNIOR, O. R. Qualidade e capacidade antioxidante total de frutos de genótipos de umbuzeiro oriundos do Semi- 
Árido Nordestino. 2008. 106 f. Tese (Doutorado em Agronomia)Universidade Federal da Paraíba, João Pessoa, 2008.

DASHWOOD, R. H. et al. Chemopreventive properties of chlorophylls toward aflatoxin B1, a review of the antimutagenicity and anticarcinogenicity data in rainbow trout. Mutation Research, v. 399, p. 245-253, 1998. http://dx.doi.org/10.1016/S00275107(97)00259-5

EMPRESA PARAIBANA DE ABASTECIMENTO E SERVIÇOS AGRÍCOLAS - EMPASA. Oferta e cotação de preços. EMPASA, 2011. Disponível em: <http://www.empasa.pb.gov.br/>. Acesso em: 04 set. 2011.

FRAIFE FILHO, G. A.; LEITE, J. B. V.; RAMOS, J. V. Cajá. CEPLAC, 2010. Disponível em: <http://www.ceplac.gov.br/radar/ caja.htm>. Acesso em 10 out. 2011.

HAMANO, P. S.; MERCADANTE, A. Z. Composition of carotenoids from commercial products of caja (Spondias lutea). Journal of Food Composition and Analysis, v. 14, p. 335-343, 2001. http://dx.doi. org/10.1006/jfca.2000.0975

HARTTIG, U.; BAILEY, G. S. Chemoprotection by natural chlorophylls in vivo, inhibition of dibenzo[a,l]pyrene- DNA adducts in rainbow trout liver. Carcinogenesis, v. 19, n. 7, p. 1323-1326, 1998. http:// dx.doi.org/10.1093/carcin/19.7.1323

IKEMEFUNA, J.; ADAMSON, I.; Chlorophyll and carotenoid changes in ripening palm fruit, Elaeis guineensis. Phytochemistry, v. 23 , n. 7 , p. $1413-1415,1984$. http://dx.doi.org/10.1016/S00319422(00)80476-8

KRINSKY, N. I.; JOHNSON, E. J. Carotenoid actions and their relation to health and disease. Molecular Aspects of Medicine, n. 26, p. 459-516, 2005. http://dx.doi.org/10.1016/j.mam.2005.10.001

KONDO, K. et al. Inhibition of LDL oxidation by cocoa. Lancet, n. 348, p. 1514-1518, 1996. http://dx.doi.org/10.1016/S01406736(05)65927-2

LARRAURI, J. A.; PUPÉREZ, P.; SAURA-CALIXTO, F. Effect of drying temperature on the stabilitity of polyphenols and antioxidant activity of red grape pomace peels. Journal of Agricultural and Food Chemistry, v. 45, p. 1390-1393, 1997. http://dx.doi.org/10.1021/ jf960282f

LEES, D. H; FRANCIS, F. J. Standardization of pigment analyses in cranberries. HortScience, v. 7, n. 1, p. 83-84, 1972.

LIMA, M. A. C.; SILVA, A. L.; AZEVEDO, S. S. N. Evolução de indicadores do ponto de colheita em manga'Tommy Atkins' durante o crescimento e a maturação, nas condições do Vale do São Francisco, Brasil. Ciência Agrotenologia, v. 33, n. 2, p. 432-439, 2009.

LORENZI, H. Frutas Brasileiras e exóticas cultivadas (de consumo in natura). São Paulo: Instituto Plantarum de Estudos da Flora, 2006. 672 p.

MANHÃES, L. R. T.; SABAA-SRUR, A. U. O. Centesimal composition and bioactive compounds in fruits of buriti collected in Pará. Ciência e Tecnologia de Alimentos, v. 31, n. 4, p. 856-863, 2011.

MAZUR, A. et al. Inhibitory effect of procyanidin-rich extracts on LDL oxidation in vitro. Atherosclerosis, n. 145, p. 421-422, 1999.

MILLER, H. E. A simplified method for the evaluation of antioxidant. Journal of the American Oil Society, v. 48, p. 91, 1971. http:// dx.doi.org/10.1007/BF02635693

MOURA, N. P. et al. Caracterização físico-química de três genótipos de cajazeiras do banco de germoplasma do IPA e do CEASA. In: JORNADA DE ENSINO, PESQUISA E EXTENSÃO DA UFRPE - JEPEX, 9., 2009. Anais... Recife: Editora da Universidade Federal Rural de Pernambuco, 2009. v. 1.
MOURA, F. T. et al. Evolução do crescimento e da maturação de frutos de cajazeira (Spondias mombin L). Proceedings of the Interamerican Society for Tropical Horticulture, v. 47, p. 231-233, 2004.

OBANDA, M.; OWUOR, P. O. Flavonol composition and caffeine content of green leaf as quality potential indicators of Kenyan black teas. Journal of the Science of Food and Agriculture, v. 74, p. 209-215, 1997. http://dx.doi.org/10.1002/(SICI)10970010(199706)74:2<209::AID-JSFA789>3.0.CO;2-4

ODIN, A. P. Antimutagenicity of the porphyrins and nonenzyme porphyrin-containing proteins. Mutation Research, v. 387, p. 55-68, 1997. http://dx.doi.org/10.1016/S1383-5742(97)00023-9

PALACE, V. P. et al. Antioxidant potentials of vitamin A and carotenoids and their relevance to heart disease. Free Radical Biology \& Medicine, n. 26, p. 746-761, 1999. http://dx.doi. org/10.1016/S0891-5849(98)00266-4

PALOZZA, P.; KRINSKY, N. I. Antioxidant effects of carotenoids in vivo and in vitro: an overview. Methods in Enzymology, n. 213, p. 403-420, 1992. http://dx.doi.org/10.1016/0076-6879(92)13142-K

PIETTA, P. G. Flavonoids as antioxidants. Journal of Natural Products, v. 63, n. 7, p. 1035-1042, 2000. http://dx.doi.org/10.1021/np9904509

RICE-EVANS, C. A.; MILLER, N. J.; PAPAGANDA, G. Structure antioxidant activity relationships of flavonoids and phenolic acids. Free Radical Biology Medicine, v. 20, p. 933-956, 1996. http:// dx.doi.org/10.1016/0891-5849(95)02227-9

RODRIGUEZ-AMAYA, D. B.; KIMURA, M. Carotenoides e valor de vitamina A em caja (Spondias lutea). Ciência Tecnologia de Alimentos, v. 9, p. 148-162, 1989.

RODRIGUEZ-AMAYA, D. B. Some considerations in generating carotenoid data for food composition tables. Journal of Food Composition and Analysis, v. 13, p. 641-647, 2000. http://dx.doi. org/10.1006/jfca.2000.0915

ROMBALDI, C. V. et al. Potencial de conservação e qualidade de frutas: Aspectos biotecnológicos de pré e pós-colheita. In: CONGRESSO BRASILEIRO DE FRUTICULTURA - CBF, 19., 2006, Cabo Frio. Palestras e resumos... Cabo Frio: SBF/UENF/UFRuralRJ, 2006. p. 105-132.

ROSA, L. A.; ALVAREZ-PARRILLA, E.; GONZÁLEZ-AGUILAR, G. $A$. Fruits and vegetables phytochemicals: Chemistry, nutritional value, and stability. Willey-Blackwell: Ames, 2010. 382 p.

RUFINO, M. S. M. et al. Determinação da atividade antioxidante total em frutas no Sistema B-caroteno/Ácido Linoléico. Fortaleza: Embrapa Agroindústria Tropical, 2006. 4 p. (Comunicado Técnico on-line, n. 126).

RUFINO, M. S. M. Propriedades funcionais de frutas tropicais brasileiras não tradicionais. 2008. $237 \mathrm{f}$. Tese (Doutorado em Fitotecnia)-Faculdade de Agronomia, Universidade Federal Rural do Semi-árido, Mossoró, 2008.

SOARES, E. B. et al. Caracterização física e química de frutos de cajazeira. Revista Brasileira de Fruticultura, v. 28, n. 3, p. 518-519, 2006. http://dx.doi.org/10.1590/S0100-29452006000300039

SOUZA, E. P. et al. Enxertia da Cajazeira. Revista Brasileira de Fruticultura, v. 32, n. 1, p. 316-320, 2010. http://dx.doi.org/10.1590/ S0100-29452010005000002

SOUZA, F. X. et al. Crescimento e desenvolvimento de clones de cajazeira cultivados na Chapada do Apodi, Ceárá. Revista Brasileira de Fruticultura, v. 28, n. 3, p. 414-420, 2006. http:// dx.doi.org/10.1590/S0100-29452006000300017

SILVA, L. R. Qualidade e atividade antioxidante de frutos de genótipos de umbu-cajazeiras (spondias sp.) oriundos da 
microrregião de Iguatu, CE. 2008. 135 f. Dissertação (Mestrado em Agronomia)-Universidade Federal da Paraíba, João Pessoa, 2008.

STATISTICAL PACKAGE FOR THE SOCIAL SCIENCES - SPSS. 14.0 for Windows Evaluation Version [Computer program]. SPSS. Inc., 2005.

STAHL, W.; SIES, H. Bioactivity and protective effects of natural carotenoids. Biochimica et Biophysica Acta, n. 1740, p. 101-107, 2005.
TODA FRUTA. Cajá (Spondias Mombin L.). Toda fruta, 2006. Disponível em: <http://www.todafruta.com.br/portal/ icNoticiaAberta.asp?idNoticia=11025>. Acesso em: 21 out. 2011.

ZULUETA, A. et al. Vitamin C, vitamin A, phenolic compounds and total antioxidant capacity of new fruit juice and skim milk mixture beverages marketed in Spain. Food Chemistry, v. 103 , n. 4 , p. 1365-1374, 2007. http://dx.doi.org/10.1016/j. foodchem.2006.10.052 